\title{
Genus Metagentiana T. N. Ho \& S. W. Liu (Gentianaceae Juss.) - a new record for flora of Vietnam
}

\author{
Khuat Van Quyet ${ }^{*}$, Ha Minh Tam $^{l}$, Nguyen Thi Thuy Hang ${ }^{l}$, and Nguyen Thanh Hai ${ }^{l}$ \\ ${ }^{1}$ Faculty of Biology and Agricultural engineering, Hanoi Pedagogical University $N^{\circ}$ 2, Hanoi, Vietnam
}

\begin{abstract}
Ho et al. proposed to exclude Stenogyne section from the genus Gentiana and classifying it as a distinct genus (Metagentiana). Fourteen species of this genus have been recorded and distributed in China, Myanmar and Thailand. This is the first time there has been a confirmed genus Metagentiana distributed in Vietnam. This genus has two species: Metagentiana rhodantha and Metagentiana primuliflora, which are proposed in Vietnam. Particularly, Metagentiana rhodantha, which had only been known from China, was reported in Vietnam. A detailed description along with their distribution, habitat, ecology, illustrations, and photos has been provided to aid species identification. The key to identify all taxa of the genus has been constructed
\end{abstract}

\section{Introduction}

Stenogyne is one of Gentiana's 16 sections, belonging to the gentian family (Gentianaceae Juss.) [1]. It was established by Franchet [2] and was revised by Kusnezov [3]. It is the most disputable and poorly known of Gentiana's 16 sections.

Genus Metagentiana was established by Ho et al [4] on the basis of removing the Stenogyne section from the genus Gentiana based on data on gross morphology, floral anatomy, chromosome number, palynology, embryology, and molecular data. Before Ho Ting Nong, many botanists considered it as a section of the Gentiana genus [5-7]. However, contrary to the point of view of many authors at that time, Smith [8] and Löve [9] based on observations of gross morphology, realized the difference between the Stenogyne section and the sections another in the genus Gentiana and its close relationship with the genera Tripterospermum and Crawfurdia. Löve and Löve (1976) proposed to transfer this section to the genus Tripterospermum, which is intended to be a new subgenus of this genus [10] also noticed this difference, but in his classification, the author classified this section as a subgenus of the genus Gentiana. Subsequent authors' karyological studies continued to support evidence that this section differs from the other sections in the genus Gentiana [11-14]. Authors [12-13] in their initial studies, published chromosome numbers for six species belong to this section; at the same time, based on their differences in the number of haploid chromosomes. They suggested to separate the location of this section within the genus Gentiana. Their subsequent research results on ITS sequencing of the DNA ribosome continued to confirm the difference of the Stenogyne section compared to other sections in the Gentiana genus [14]. Thereafter, species of this section continue to be studied by many authors in a relatively comprehensive way [15-26]. Based on the summary of research data of previous authors and based on their own research, suggested removing Stenogyne section from the genus Gentiana and classifying it as a distinct genus (Metagentiana) [4]. They affirmed that this new genus was more related to Tripterospermum and Crawfurdia than to Gentiana, though it was more primitive than the first two genera; together with Tripterospermum and Crawfurdia the new genus formed a monophyletic group, which was the sister group to the genus Gentiana [4]. Fourteen species (China - thirteen species; Myanmar - one species and Thailand - one endemic species) of the genus Metagentiana have been proposed. The species of this genus are mainly distributed in high mountains, grassland, and coniferous forests.

In Vietnam, Loureiro [27] was the first botanist to study on Gentiana genus; two species of this genus have been recorded by the author to be distributed in Vietnam. The "Flore du Cambodge, du Laos et du Vietnam" [28] is considered the most complete classification work of this genus in Vietnam; nine species of the genus distributed in Vietnam were authored detailed description, including Gentiana primuliflora species (belonging to Stenogyne section) which was first recognized by the author to be distributed in Vietnam, it was previously endemic to China.

During the course of revisionary on the Gentianaceae in Vietnam, interest arose in the specimens, which were housed in the herbarium of Institute of Ecology and Biological Resource, Hanoi (HN). After thorough morphological study with the help of the relevant literature [1,4, 27-30], it was identified as Metagentiana rhodantha (Franch.) T. N. Ho \& S. W. Liu, a new distributional record for Vietnam. This taxon was so far known only from China [4] and had never been recorded in Vietnam.

Earlier, Hul Sovanmoly [28] recorded species Gentiana primuliflora Franch.in Vietnam, distributed in

\footnotetext{
* Corresponding author: khuatvanquyet@hpu2.edu.vn
} 
Da Lat city (Lam Dong province). The specimen is currently stored in herbarium of Hanoi National University (HNU) and Muséum National d'Histoire Naturalle, Paris (P). We have been revised this species name to Metagentiana primuliflora (Franch.) T. N. Ho \& S. W. Liu...

This is the first time there have been a confirmed genus Metagentiana distributed in Vietnam. This genus has two species: Metagentiana rhodantha and Metagentiana primuliflora, which are proposed in Vietnam. In this article, we describe the characteristic of genus Metagentiana and two specises of this genus in Vietnam along with brief information about their distribution, habitat and ecology; illustrations and photos have been provided to aid species identification. The key to identify all taxa of the genus has been constructed.

\section{Material and methods}

The study area covers the entire territory of Vietnam. The collected specimens were processed and preserved in the herbarium of Institute of Ecology and Biological Resource, Hanoi (HN). In addition, we also researched dry specimens that were kept in the herbarium of Hanoi National University (HNU); the herbarium of Institute of Ecology and Biological Resource, Hanoi (HN); the herbarium of National Institute of Medicinal Materials (HNMM); Botanical Museum - Institute of Tropical Biology, Ho Chi Minh City (VNM). The total samples studied are 46 specimens belong to the genus Gentiana and 6 specimens belong to the genus Metagentiana. On the other hand, photographs of herbarium sheets were obtained (or downloaded) from A, BM, E, GH, K, M, MO, NY, P, S, and UPS. The identification of the species belonging to these two genera was confirmed in consultation with standard literature [1,4,27-30]. Updated nomenclature is determined consulting The Plant List (2020), a working list of all plant species.

\section{Taxonomic treatment}

Metagentiana T. N. Ho \& S. W. Liu, 2002. Bot. Bull. Acad. Sin. 43(1): 89. - Gentiana sect. Stenogyne Franchet, 1884. Bull. Soc. Bot. France, 31: 375. - Gentiana subgen. Stenogyne (Franchet) Halda, 1995. Acta Mus. Richnov. 3: 29. W. Liu

Type: Metagentiana primuliflora (Franchet) T. N. Ho \& S.

Herbs annuals or perennials. Stems erect; branches spreading, 4-angled. Leaves opposite, sessile to subsessile; leaves blade usually elliptic, ovate to cordate, margin serrulate, base rounded to cordate, apex acute; veins 3 or 5. Flowers terminal on branches, solitary, 5-merous, sessile, subtended by a pair of leaf-like bracts. Calyx tubular; tube membranous, 5angled; lobes 5, midvein prominent outside and decurrent into angles of calyx tube. Corolla tubular to funnelform or salverform; tube usually much longer than lobes, lobes triangular or ovate; plicae between lobes, asymmetrical, very oblique, margin long fringed or erose. Stamens 5, unequal; filaments inserted on corolla tube; anthers narrowly ellipsoid. Ovary superior, 1-locular, ellipsoid; style filiform, about as long as ovary; stigma 2-lobes, linear. Capsule included in persistent corolla, ellipsoid, wingless, many seeded. Seeds brown, triquetrous, ellipsoid, ovoid to subglobose, winged or wingless.
In the world, fourteen species of the genus Metagentiana have been recorded, distributed in China, Myanmar, and Thailand. In Vietnam, two species have been recorded of this genus, distributed in north and central Vietnam.

Key to species of two genera Metagentiana and Gentiana in Vietnam

1a. Flowers solitary at the top of the branches; leaf sessile to subsessile, base leaf cordate; stamens commonly unequal; seeds triquetrous; calyx tube with 12 vascular bundles . Metagentiana T. N. Ho \& S. W. Liu (2)

1b. Flowers many, paired or fasciculate (except Gentiana loureiroi); leaf petiolate, base leaf commonly attenuate (rarely rounded); stamens equal; seed not triquetrous; calyx tube with 15 vascular bundles Gentiana L. (3)

2a. Perennials; corolla pale purple; plicae margin fringed; seeds broadly winged ........................ Metagentiana rhodantha

2b. Annuals; corolla pale blue to violet blue; plicae margin erose; seeds wingless ........................Metagentiana primuliflora

3a. Calyx lobes unequal (2 larger than other 3); seed coat alveolate.

3b. Calyx lobes equal; seed coat rugose ......................... (5)

4a. Basal rosettes usually well developed; lowermost stem leaves not scalelike but with expanded herbaceous blades ..Gentiana cephalantha

4b. Basal rosettes none or poorly developed; lowermost stem leaves scale like, membranous ................... Gentiana rigescens

5 a. Flowers \pm solitary on short to long branches

Gentiana loureiroi

5b. Flowers many, paired or fasciculate (6)

6a. Stems stoloniferous; corolla plicae with the margin obliquely truncate; capsule wingless ................ Gentiana lowryi

6b. Stems not stoloniferous; corolla plicae with a free part; capsule winged

7a. Corolla scarcely exceeding calyx; calyx lobes ovatespathulate ............................................ Gentiana moniliformis

7b. Corolla usually twice as long as calyx; calyx lobes triangular.....

8a. Herb with stems \pm erect, sometimes exceeding $10 \mathrm{~cm}$ tall; stems angled

8 b. Herb \pm caespitose, \pm tufted, never more than $10 \mathrm{~cm}$ tall; stems not angled .............................................................. (10)

9a. Corolla tube narrowly campanulate; ripe capsules completely exserted, obovoid to widely obovoid ........ Gentiana langbianensis

9b. Corolla tube infundibuliform; ripe capsules \pm exserted, \pm obovoid ................................................... Gentiana jouyana

10a. Leaves elliptic-oblong or oblong, sometimes spathulate; ripe capsule \pm exserted

Gentiana greenwayae

10b. Leaves elliptic or subobovate; ripe capsule included

Gentiana tonkinensis

- Metagentiana rhodantha (Franch.) T.N. Ho \& S.W. Liu, 2002. Bot. Bull. Acad. Sin. 43(1): 89. Gentiana rhodantha Franch. in Forbes \& Hemsl. 1890. J. Linn. Soc. Bot. 26: 133; Kusnez. 1896-1904. Acta Hort. Petrop. 15: 251; Forrest. 1907. Not. Bot. Gard. Edinb. 4: 70; Lévl. 1914-1915. Fl. Kouy-Tcheou: 172; id. 1916. Cat. Pl. Yunnan: 114; Hand.-Mazz. 1936. Symb. Sin. 7: 951; T.N. Ho, 1988. Fl. Reipubl. Popul. Sin. 62: 24; T.N. Ho \& J.S. Pringle in Wu Z.Y. \& Raven P.H. (eds.), 1995. Fl. China, 16: 61. - Gentiana jankae Kanitz, 1891. Pl. exped. Szechenyi in As. centr. coll.: 41. - Gentiana rhodantha Franch. var. wilsonii Marquand, 1928. Bull. 
Misc. Inform. Kew.: 55. Type: China (Tapintze - NW Yunnan). Delavay 1869 (Lectotype: $\mathrm{P}$ photo 1; isolectotypes: BM, K, UPS).

Vernacular name: Long đởm tua

Perennials $25-52 \mathrm{~cm}$ tall, with a short rhizome. Stems erect; branches spreading, 4-angled. Leaves opposite, sessile to subsessile; leaf blade elliptic, ovate to cordate, $1.5-4$ by $0.5-2 \mathrm{~mm}$, margin serrulate, base narrowed, rounded to cordate, apex acute; veins 3 or 5 . Flowers terminal, solitary, 5-merous, sessile; bracts foliaceous, ovate-triangular, $0.8-1.5$ by $0.4-1 \mathrm{~mm}$, margin serrulate, base narrowed, rounded to cordate, apex acute. Calyx tubular, narrowly obconic; tube long 8-12 mm, membranous, 5-angled; lobes 5, linear-lanceolate, long 5$7 \mathrm{~mm}$, midvein prominent outside and decurrent into angles of calyx tube. Corolla tubular to funnelform, pale purple; tube long 2-4 cm; lobes ovate, long 5-8 mm, margin entire, apex obtuse; plicae broadly triangular, long 4-5 mm, apex long fringed. Stamens 5, unequal; filaments inserted at basal part of corolla tube, long 8-12 mm; anthers narrowly ellipsoid, long 2-3 $\mathrm{mm}$. Ovary superior, 1-locular, ellipsoid; style long 6-8 mm; stigma 2-lobes, linear. Capsule included in persistent corolla, ellipsoid, long 2-2.5 cm, gynophore 3.5-5 mm. Seeds light brown, triquetrous, ellipsoid to subglobose, $0.6-1$ by $0.5 \mathrm{~mm}$, broadly winged. (Fig. 2)

Habitat \& Ecology: Grasslands, alpine scrub or forests; at an altitude of 1000-2000 m.

Phenology: Flowering: November to December; Fruiting: January.

Ditribution: Vietnam: Ha Giang (Dong Van district); China (Yunnan, SW Sichuan, Guizhou, W Hubei, Henan, Gansu, S Shaanxi, Shanxi, Guangxi).

Specimens examined: Ha Giang, Ban-Bien-HiepKhoi 19 (HN).

- Metagentiana primuliflora (Franch.) T.N. Ho \& S.W. Liu, 2002. Bot. Bull. Acad. Sin. 43(1): 89. Gentiana primuliflora Franch. 1884. Bull. Soc. Bot. France, 31: 375; F. Forbes \& Hemsl. 1890. J. Linn. Soc. Bot. 26: 132; Kusnez. 1896-1904. Acad. Hort. Petrop. 15: 253; Hand.-Mazz. 1936. Symb. Sin. 7: 952; T.N. Ho, 1988. Fl. Reipubl. Popul. Sin. 62: 154; T.N. Ho \& J.S. Pringle in Z.Y. Wu \& P.H. Raven (eds.), 1995. Fl. China, 16: 62; Hul, 2003. Fl. Camb. Laos Vietn. 31: 30. Type: China (Mo che tchin - Yunnan). Delavay Gent. n. 9 (Holotype: P photo 1.).

Vernacular name: Long đởm Anh thảo

Annuals 4-22 cm tall. Stems \pm erect; branches spreading, 4-angled. Leaves opposite, sessile to subsessile; leaf blade ovate to cordate, $3-10$ by $2-7 \mathrm{~mm}$, margin serrulate, base rounded to cordate, apex acute; veins 3 or 5 . Flowers terminal, solitary, 5-merous, sessile or subsessile; bracts foliaceous, $4-5$ by $2-3 \mathrm{~mm}$, apex acute. Calyx tubular; tube long 8-10 mm, membranous, 5angled; lobes 5 , triangular to subulate, $1.5-2$ by $0.5 \mathrm{~mm}$, midvein prominent outside and decurrent into angles of calyx tube. Corolla salverform, pale blue to violet blue; tube long $8-14 \mathrm{~mm}$; lobes triangular, $5-8$ by $3 \mathrm{~mm}$, margin entire, apex obtuse; plicae triangular, $2.5-3$ by $1-2 \mathrm{~mm}$, margin erose. Stamens 5, unequal; filaments inserted at middle of corolla tube, long 5-8 $\mathrm{mm}$, linear; anthers narrowly ellipsoid, long 1-2 mm. Ovary superior, 1locular, ellipsoid; style long 4-6 mm; stigma 2-lobes, linear. Capsule included in persistent corolla, ellipsoid, 814 by $2-3 \mathrm{~mm}$, gynophore ca. $2 \mathrm{~mm}$. Seeds brown, triquetrous, ellipsoid to ovoid, 1 by $0.5-1 \mathrm{~mm}$, wingless. (Fig. 3)

Habitat \& Ecology: Grassland slopes or forests; at an altitude of $1500-2000 \mathrm{~m}$.

Phenology: Flowering: October to November; Fruiting: December.

Ditribution: Vietnam: Lam Dong (Pren waterfall, Da Lat city); China (NW \& C Yunnan, SW Sichuan).

Specimens examined: Lam Dong, Evrard 1468 (HNU, P), 2218 (HNU, P).

\section{Conclusion}

In this study, we agreed with Ho et al. (2002) [4] when proceeding to separate Stenogyne section from the genus Gentiana and classify it as a separate genus (Metagentiana). During the research, we have classified nine species of the genus Gentiana (Fig. 1) and two species of the genus Metagentiana that are distributed in Vietnam. This is the first time there has been a confirmed genus Metagentiana distributed in Vietnam. This genus has two species: Metagentiana rhodantha and Metagentiana primuliflora, which are proposed in Vietnam. Particularly, Metagentiana rhodantha, which had only been known from China, was reported in Vietnam. A detailed description along with their distribution, habitat, ecology, illustrations, and photos has been provided to aid species identification. The key to identify all taxa of the genus has been constructed.

\section{Authors' contributions}

This study was performed in collaboration between all authors. The two first authors, Khuat Van Quyet and Nguyen Thanh Hai, were the main investigators of the study. Other authors participated in the collection of materials, the preparation of experiments, and data collection. Kalashnikova E.A. designed the study, wrote the manuscript, and is the corresponding author of this research.

\section{References}

1. T. N. Ho and J. S. Pringle, "Gentianaceae," in Flora of China, vol. 16, Z. Y.Wu and P. H. Raven, Eds. Beijing/St Louis: Science Press/Missouri Botanical Garden, 1-140 (1995)

2. M. A. Franchet, "Description de quelques espéces de Gentiana du Yun-nan," Bulletin de la Société Botanique de France, 31, pp. 373-378 (1884)

3. N. I. Kusnezov, Tproceedings of the St. Petersburg Society of Natural Scientists, 24, 1-507, (1894)

4. T. N. Ho, S. L. Chen, and S. W. Liu, "Metagentiana, a new genus of Gentianaceae," Botanical Bulletin of Academia Sinica, 43, pp. 83-91 (2002) 
5. J. S. Pringle, "Sectional and subgeneric names in Gentiana (Gentianaceae)," Contributions to Botany, 7, pp. 232-247 (1978)

6. T. N. Ho and S. W. Liu, "The infrageneric classification of Gentiana," Bull. Brit. Museum Bot, 20, pp. 169-192, (1990)

7. L. Struwe, J. W. Kadereit, J. Klackenberg, S. Nilsson, M. Thiv, K. B. Von Hagen, and V. A. Albert, "Systematics, character evolution, and biogeography of Gentianaceae, including a new tribal and subtribal classification," in Gentianaceae: systematics and natural history, L. Struwe and V. A. Albert, Eds. Cambridge: Cambridge University Press, pp. 21-309 (2002)

8. H. Smith, Notes from Royal Botanic Garden (Edinburgh), 26, pp. 237-258 (1965)

9. A. Löve and D. Löve, "Natural genera of Gentianinae," in Recent Advances in Botany, P. Kachroo (Dehra Dun, Delhi, pp. 205-222, 1976)

10. J. J. Halda, "Acta Musei Richnoviensis Section Nature, 3, pp. 25-29, (1995)

11. Y. M. Yuan, Cytologia, 46, pp. 99-114 (1993)

12. Y. M. Yuan and P. Küpfer, Bulletin de la Société Neuchâteloise des Sciences Naturelles, 116, pp. 6578, (1993)

13. Y. M. Yuan and P. Küpfer, Cytologia, 58, pp. 115123, (1993)

14. Y M Yuan, P. Küpfer, and J. J. Doyle, American Journal of Botany, 83, 641-652 (1996)

15. S. L. Chen, T. N. Ho, and J. Q. Liu, "Acta Botanica Boreali-Occidentalia Sinica, 17, pp. 547-550 (1997)

16. S. L. Chen, T. N. Ho, and D. Y. Hong, Journal of Systematics and Evolution, 36, pp. 58-68 (1998)
17. S. L. Chen, T. N. Ho, J. Q. Liu, and D. Y. Hong, Acta Biologica Plateau Sinina, 14, pp. 26-34 (1999)

18. S. L. Chen, T. N. Ho, J. Q. Liu and D. Y. Hong, Acta Biologica Plateau Sinina, 14, pp. 35-46 (1999).

19. S. L. Chen, T. N. Ho, J. Q. Liu, and D. Y. Hong, Acta Bot. Yunnan, 22, pp. 53-58 (2000)

20. T. N. Ho and J. Q. Liu, "Acta Bot. Bor.-Occid. Sinica, 19, pp. 234-240 (1999)

21. T. N. Ho, J. Q. Liu, and D. C. Zhang, Acta Biol. Plateau Sin, 13, pp. 9-19 (1997)

22. T. N. Ho, W. Wang, and C. Y. Xue, Acta Botanica Boreali-occidentalia Sinica, 19, pp. 546-551 (1999)

23. J. Q. Liu and T. N. Ho, Acta Biol. Plateau Sinica, 13, pp. 31-41 (1997)

24. J. Q. Liu, C. Y. Xue, and T. N. Ho, Journal of Northwest Normal University (Natural Science), 34, pp. 59-66 (1998)

25. C. Y. Xue, T. N. Ho, and J. Q. Liu, Journal of Systematics and Evolution, 37, pp. 259-263 (1999)

26. C. Y. Xue, T. N. Ho, and J. Q. Liu, Acta Botanica Yunnanica, 21, pp. 212-217 (1999)

27. J. Loureiro, Flora cochinchinensis, 1st ed. (Berolini, 2020)

28. S. Hul, Flore du Cambodge, du Laos et du Viêt-Nam: révision de la Flore générale de l'Indochine, 31, Muséum national d'Histoire naturelle (2003)

29. F. Gapnepain, Flore Générale de L'Indo-Chine, 4, Paris: Muséum National d'Histoire Naturelle, Laboratoire de Phanérogamie (1912)

30. P. H. Ho, An illustrated flora of Vietnam, vol. 2, Hanoi: Young Publishing House, pp. 676-677 (2000) 


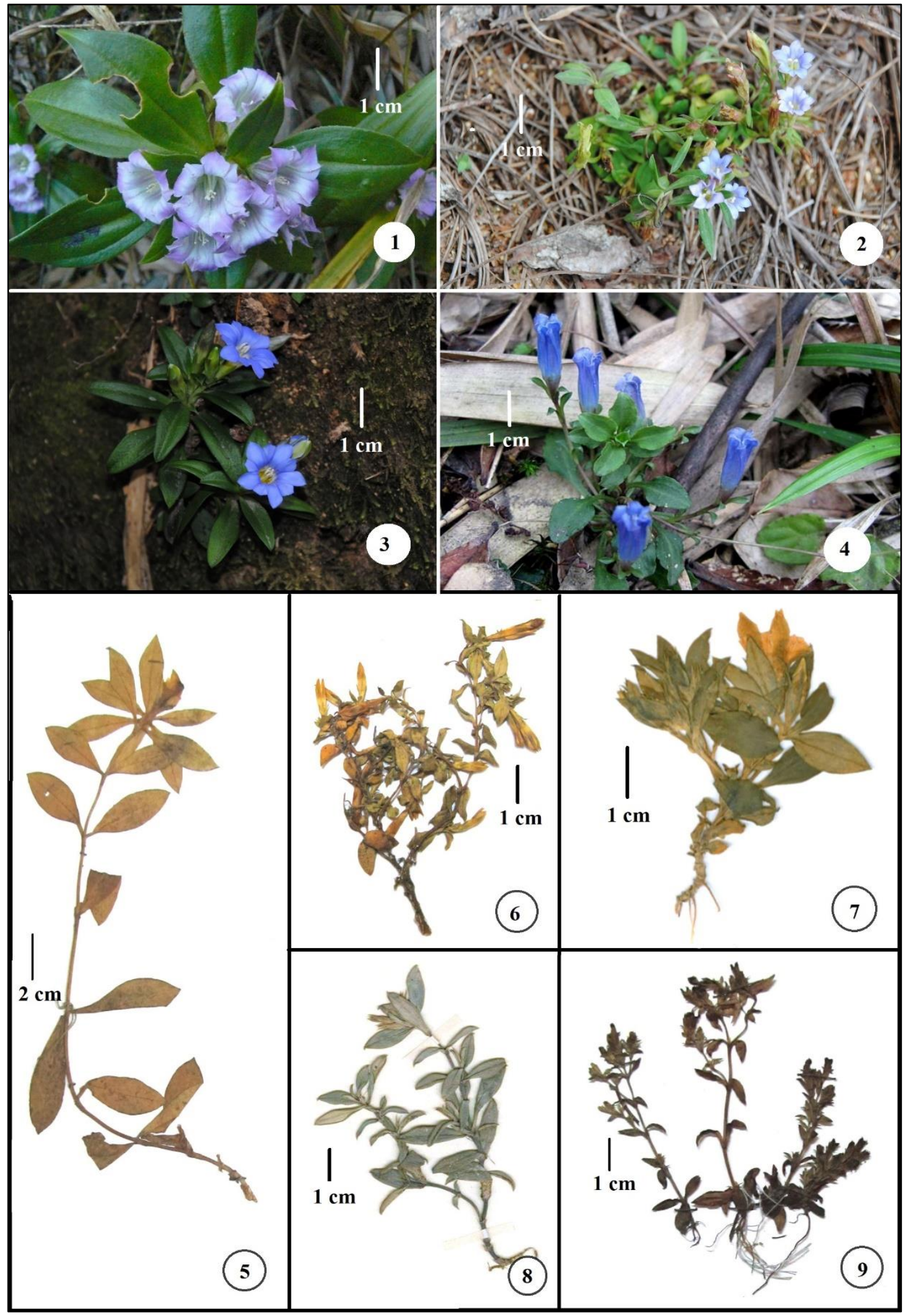

Fig.1 Gentiana species are distributed in Vietnam: 1. G. cephalantha Franch. (Fan Si Pan at an altitude of $2400 \mathrm{~m}$, Lao Cai province, photo by Khuat Van Quyet, 2012); 2. G. loureiroi (G. Don) Griseb. (Lam Dong province, photo by Tran The Bach, 2012); 3. G. greenwayae Merr. (Lam Dong province, photo by Tran The Bach, 2012); 4. G. lowryi Hul (Fan Si Pan at an altitude of 2500 m, Lao Cai province, photo by Khuat Van Quyet, 2012); 5. G. rigescens Franch. (photo by Khuat Van Quyet, 2013 , based on specimens Le Kim Bien 7808 (HN)); 6. G. langbianensis A. Chev. ex Hul (photo by Khuat Van Quyet, 2013, based on specimens VH 3844 (HN)); 7. G. tonkinensis Hul (photo by Khuat Van Quyet, 2013, based on specimens Pételot 5735 (HNU)); 8. G. jouyana Hul (photo by Khuat Van Quyet, 2013, based on specimens Poilane 3561 (HNU)); 9. G. moniliformis C. Marquand (photo by Khuat Van Quyet, 2013, based on specimens CBL 1382 (HN)). 


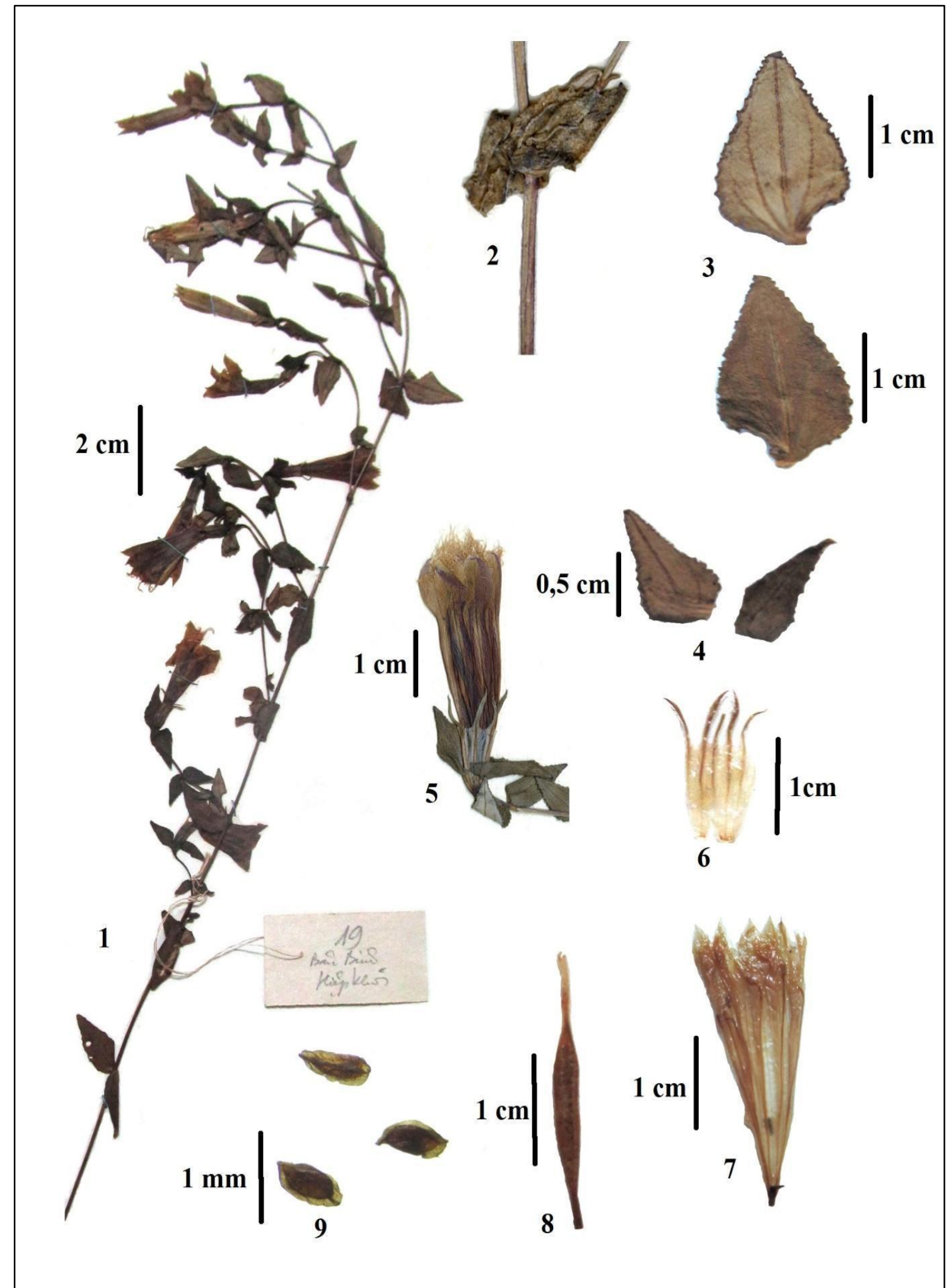

Fig.2 Metagentiana rhodantha (Franch.) T.N. Ho \& S.W. Liu; - 1. Flowering branch; 2. Showing angled on the stem; 3 . Leaf; 4. Bracts foliaceous; 5. Flower; 6. Opened calyx abaxial view; 7. Opened corolla showing stamens; 8. Fruit; 9. Seeds broadly winged (photo by Khuat Van Quyet, 2013, based on specimens Ban-Bien-Hiep-Khoi 19 (HN)). 


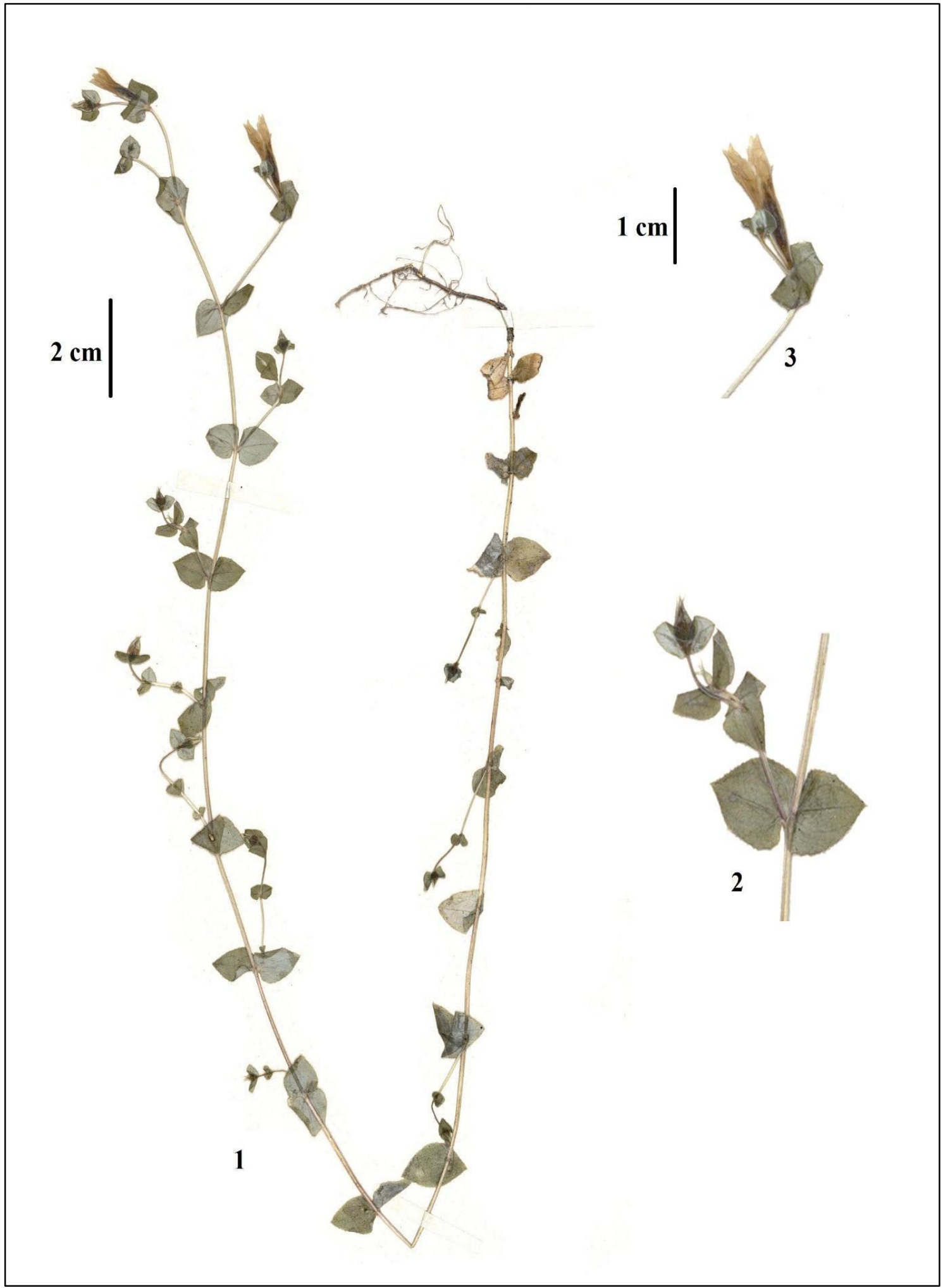

Fig.3 Metagentiana primuliflora (Franch.) T.N. Ho \& S.W. Liu; - 1. Flowering plant; 2. A pair of leaves and flowering branch; 3. Flower (photo by Khuat Van Quyet, 2013, based on specimens Evrard 1468 (HNU)) 